\title{
Too many PhDs? An invalid argument for countries developing their scientific and academic systems: The case of Portugal
}

\author{
João M. Santos ${ }^{\mathrm{a}, \mathrm{b}, *}$, Hugo Horta ${ }^{\mathrm{c}}$, Manuel Heitor ${ }^{\mathrm{b}, 1}$ \\ a Instituto Universitário de Lisboa (ISCTE-IUL), Centro de Investigação e Intervenção Social (CIS-IUL), Lisboa, Portugal \\ b Center for Innovation, Technology and Policy Research, Instituto Superior Técnico, Technical University of Lisbon, Portugal \\ c Division of Policy, Administration and Social Sciences Education, Faculty of Education, The University of Hong Kong, Pokfulam, Hong Kong, China
}

\section{A R T I C L E I N F O}

\section{Article history:}

Received 1 December 2014

Received in revised form 10 December 2015

Accepted 23 December 2015

Available online 12 January 2016

\section{Keywords:}

Doctoral education and employability

Stock of doctorate holders

Flow of new doctorates

Skilled labor

Skilled labor markets

\begin{abstract}
A B S T R A C T
This article contradicts recent arguments in Portugal that there are "too many PhDs" and argues that there is a need to understand better the changing nature of doctorates and doctorate holders. The article analyzes whether there is a surplus of doctorate holders in Portugal based on five critical dimensions, using data provided by supranational and national public organizations: stocks and flows; university academic staff qualifications; age structure; research output; and labor market for PhDs. The analysis shows that rather than a surplus, there is a shortage of doctorate holders in many sectors of activity, which is expected to be exacerbated in the next few decades. These findings underline the need to consider active public policies to attract and retain PhDs, as well as enhancing the degree of involvement of new doctorate holders in the modernization of higher education and in the internationalization of the economy. Intermediary institutions, public-private research partnerships and public administration may play a critical role in the process but require new economic actors and instruments with the capacity to invest in and employ doctorate holders.
\end{abstract}

(c) 2015 Elsevier Inc. All rights reserved.

\section{Introduction}

Disparities in economic development between countries have highlighted differences that cannot be attributed to natural resources and demographics alone (Phelps, 2013). These differences draw attention to the role that skilled people play as critical resources in fostering science, innovation, competitiveness and development in global knowledge economies (De, 2014). The relevance of knowledge and of skilled people has brought to the policy agenda of governments worldwide the need to modernize science and higher education systems and institutions to cope with the complex economic, societal, cultural and scientific challenges that modern societies face (Scott, 2000). This includes doctoral training because PhDs have a substantial ability in recombining existing knowledge and articulating it in novel ways, paving the way for a multitude of innovations (Forfás, 2009), even if they represent a relatively small proportion of skilled workers.

Doctorate holders are expected to acquire a combination of technical and soft skills, transferable competencies, behaviors and high levels of adaptability during their studies (Durette et al., 2014). These competences remain unchanged, despite the fact that doctoral training has been undergoing transformation in recent times (Wildy et al., 2013).

\footnotetext{
* Corresponding author at: Instituto Universitário de Lisboa (ISCTE-IUL), Centro de Investigação e Intervenção Social (CIS-IUL), Lisboa, Portugal.

E-mail addresses: jmcsm@iscte.pt (J.M. Santos), horta@hku.hk (H. Horta), mheitor@ist.utl.pt (M. Heitor).

1 The three authors contributed equally to this article.
}

However, concurrent with recent changes in doctoral training, claims have been put forward that "too many PhDs" are being trained (Cyranoski et al., 2011). These claims have been fueled to a large extent by the media, based on data of mature science and technology systems ${ }^{2}$ (Larson et al., 2014; Stephan, 2012a). The rapid increase in contingentstaff at US and UK universities is one of the most visible facets of this phenomenon, and it is undisputable that, in many scientific systems, doctoral graduates are facing increasingly precarious employment prospects (Stephan, 2012b). ${ }^{3}$

This has become an alarming situation for the doctoral graduates themselves and for the sustainability of these scientific systems (Schwartz, 2014). However, to what extent is this an issue that pertains to scientific systems still in their developing stages? This is a matter of key importance because discourses of "too many PhDs", which originate from mature scientific systems, are often taken as truths in systems where such claims may not apply. Moreover, they may lead to misguided policies that hamper the development of science in those countries developing their scientific systems.

The assessment of the "too many PhDs" claim in a country that is developing its scientific and academic system is the focus of this article.

\footnotetext{
2 E.g., Weissmann, J. "The PhD Bust: America's Awful Market for Young Scientists - in 7 Charts", The Atlantic, Feb. 20 2013: http://www.theatlantic.com/business/archive/2013/ 02/the-phd-bust-americas-awful-market-for-young-scientists-in-7-charts/273339/.

3 This, in part, is also due to concerns which have been emerging regarding the quality of doctoral education given the rising number of doctoral programs and sometimes unclear or conflicting quality-assurance regulations (see for example Byrne et al., 2013); although relevant, this is a topic which is beyond the scope of this article.
} 
The focus of our analysis is Portugal - a country with a poorly qualified workforce in European average terms, facing structural barriers to economic growth in recent years (Carneiro et al., 2014). It is also a country that has witnessed one of the fastest developments of its scientific system at the onset of the 21st century (Heitor et al., 2014), but where the argument that there are "too many PhDs" is gaining much attention from the national mass media and has been partly used to justify substantial public budget cuts in recent years (Rodrigues and Heitor, 2015). These have included a significant cut in grants awarded to new doctoral students per year, with the number of grants reduced from about two thousand new grants awarded in 2009 and 2010 to less than thirteen hundred in $2012 .{ }^{4}$ This context, associated with the fact that the country continues to develop its scientific system, makes it an interesting case study to analyze to what extent the claim of "too many PhDs" is applicable to countries developing their scientific capacity.

Similarly to other studies about doctoral holders (e.g., Pedersen, 2014), the analysis is based on secondary data mostly sourced from the OECD's Career of Doctorate Holders (CDH) survey, which started to be implemented in 2006. This dataset is, to the best of our knowledge, the only dataset that provides comparable data concerning stocks of doctorates for several countries. Our analysis of $\mathrm{PhD}$ stocks is complemented by our own (properly identified) estimations based on both CDH data on stocks as well as number of new PhDs per year (data retrieved from Eurostat). Other data sources, such as the Portuguese Ministry of Science and Education (and its directorates) are also used when appropriate. The article's finding is based largely on analyzing data trends but correlations are also provided in some instances for informative purposes.

The findings of this article show that for countries that have not achieved the critical mass, research proficiency and human resource qualification levels of more developed countries, the "too many PhDs" argument may not be valid. Our rationale for this assertion is based on three main reasons. First, new PhDs are required to improve the qualifications of academic staff and modernize the higher education system, being the PhD a pre-requisite for quality scholar activities both in teaching and in research (Cishe, 2014). Second, new PhDs are major drivers of knowledge production at universities, which increasingly rely on doctoral training to foster new findings and promote new research areas and themes (Larivière, 2011). Third, the low rates of PhDs employed in sectors outside academia represent both a challenge and an opportunity for the employment of PhDs. It is a challenge, since many low and medium technology businesses have limited use for doctorate holders but also an opportunity, because as national economic structures evolve and businesses develop products and services further up in the value chain, so does increase the demand for highly qualified human resources. In this context, a large stock of new PhDs needs to be available for these sectors to meet the demands of the global economy (see, for example, the evidence described by Phelps, 2013, and Chaloff and Lemaitre, 2009).

This article is organized as follows. The next section discusses the changing nature of PhDs. Section 3 provides background context for the Portuguese case. Section 4 discusses the Portuguese case, with respect to five analytical issues: i) The stock and flow of PhDs in Portugal compared with other countries in Europe; ii) the qualification level of higher education teaching staff; iii) the aging of the doctorate holder population and academic staff; iv) the evolving level of scientific production; and v) the non-academic labor market for PhDs. Section 5 discusses the data and facts presented, and justifies our main argument, which is summarized in the last section, together with policy implications.

\footnotetext{
${ }^{4}$ Source: Fundação para a Ciência e Tecnologia: http://www.fct.pt/images/stat/B6_en. gif [accessed on the 9th of July 2015.
}

\section{The changing nature of PhDs}

Obtaining a doctorate degree is considered a high educational achievement, and the starting point of a research career (Jairam and Kahl, 2012). Traditionally, a PhD was pursued mainly by those of a strictly academic persuasion, intent on spending their lives in academia and engrossed in research and teaching endeavors (Delanty, 2002). The dawn of global knowledge societies and the rise of mass education led to a multitude of higher education reforms worldwide, and to universities and academics adapting to new times (Bleiklie and Kogan, 2007; Heitor et al., 2014; Cattaneo et al., 2014). These adaptations included challenging some of academia's basic values (such as collegiality; see Ferlie et al., 2008) and the traditional idea of doctoral education, among others (Usher, 2002).

Although doctoral training has maintained its focus on research, doctoral students are increasingly being asked to acquire diverse, transferable and flexible skillsets that enable them to adapt to work in sectors other than higher education and research (Jackson, 2013). Their emerging role is not limited to research, and some studies have found PhDs working in industry to have less of a "taste for science" than those working in academia (Roach and Sauermann, 2010). The increasing number of PhDs moving into sectors other than academia can be interpreted as a tacit recognition of the importance of $\mathrm{PhDs}$ to the knowledge economy (Castro-Cruz and Sanz-Menéndez, 2005). For example, in the US, whereas in the 1960 s, it was estimated that $85 \%$ of doctorate recipients took on academic positions, in 1994-1998 only 36\% took on full-time positions at universities (Pion et al., 2003).

The fact that more PhDs began to be employed in non-academic sectors, necessarily because of a lack of positions in academia or because of their desire to work outside academia (Enders, 2002), led some universities - in times of growing accountability - to transform their PhD program training to increase employability and efficiency (Cuthbert and Molla, 2014). Many PhD programs now are intended to develop specific workplace skills perceived as desirable by employers to the detriment of knowledge production skills (Craswell, 2007). New types of doctoral training have emerged to meet new professional options for doctoral students. A paradigmatic case is the "professional $\mathrm{PhD}$ ", which aims to provide specific training to those who seek to work outside academia (Fenge, 2009). Entrepreneurship and knowledge transfer skills have been particularly highlighted in many programs worldwide, in association with the ultimate goal to foster skills for the creation of new science-based firms (Breschi et al., 2014).

Also, many universities worldwide are increasingly adopting the practice of "PhD by publications" as a pragmatic approach towards doctorate training (Jackson, 2013) that increases the levels of knowledge productivity, together with the visibility of new doctorate holders (Horta and Santos, 2015). However, there is some evidence that those who pursue non-traditional doctoral programs are not necessarily departing academia but remain there with a different profile from those pursuing traditional PhDs (Wellington and Sikes, 2006).

For all the changes to doctoral training, studies show that the motivation to undertake a $\mathrm{PhD}$ remains unchanged and continues to be mainly aligned with interest in independent work, curiosity-driven engagement, and the influence of family and learning agents (including influential university faculty). These motivations are less related with financial incentives, downstream work and access to resources (Guerin et al., 2015; Roach and Sauermann, 2010; Zhou, 2014). In general, doctoral students are interested in learning skills that are not necessarily those for which there is a demand in non-academic sectors, and this has been discussed in the literature as a major challenge to the employment of doctorate holders in non-academic sectors (see De Grande et al., 2014). It is also clear that financial motivation has not been critical for many doctoral applicants (Guerin et al., 2015; Roach and Sauermann, 2010; Zhou, 2014), although studies present mixed findings concerning the salary premium of holding a PhD when compared 
to other higher education degrees (e.g., Casey, 2009 vis-a-vis Mertens and Robken, 2013).

These issues are important because the emerging discourse associated with the "too many PhDs" argument concerns mainly the employment prospects of doctorate holders. These concerns have three dimensions. First, the difficulties that doctorate holders report in finding jobs aligned with their qualifications (Canal Domínguez and Muñiz Pérez, 2012) have fueled the argument that more PhDs are not required, a discussion that is prevalent in countries with large number of doctorates (Cyranoski et al., 2011).

Second, unemployment has an impact on the attractiveness of research to young people. An argument being forwarded is that too much competitiveness is detrimental in the long term, as outstanding students are either "scared away" from research altogether (Alberts et al., 2014), or migrate to countries where employment is more viable although not necessarily more stable or permanent (Cantwell, 2011) in order to pursue a research career (Regets, 2007). However, there are many reasons to believe that this may be a matter of perception, as data from the Careers of Doctorate Holders survey (i.e., CDH 2009) indicate that doctorates have a low unemployment rate, with an average of $1,2 \%$ in all the countries participating in the survey - which is very low, even if compared with other skilled human resources (Auriol, 2010; Maldonado et al., 2013; Milesi et al., 2014).

Third, PhDs are facing increasingly unpredictable and unsatisfactory career prospects in academia, where contingent faculty, postdoctoral positions followed by more postdoctoral positions, and limited research and academic freedom is the expected career path (Miller and Feldman, 2014).

Overall, the concept of doctoral education is broadening and changing alongside other societal changes and transformations in scientific and higher education systems. The key issue concerns the extent to which there are too many or too few PhDs being trained, since the role and importance of doctorates to scientific and academic systems remains unaffected.

\section{Background: the Portuguese case}

Until the mid-1980s, the Portuguese higher education system did not have the capacity to train PhDs in general, and there was a lack of critical mass in many scientific areas (Santos and Horta, 2015). Thus, science policies continuously fostered doctoral training abroad, resulting in a continuous brain drain (Rodrigues and Heitor, 2015). After two decades, and starting from the 1990s, the mobility of human resources at the doctoral level was assumed as a policy strategy to create the foundations of a scientific and academic basis in Portugal upon the return of doctorate holders trained abroad, as well as a means to internationalize Portuguese scientific and academic communities (Horta, 2010). As a result, brain drain and brain circulation coexisted over time, although leading, many times, to academic inbreeding practices particularly at the oldest universities (Tavares et al., 2015).

A significant growth was observed in the number of publications, with Portugal's science base in the fields of science, technology, engineering, and mathematics becoming internationally competitive. However, it took almost four decades to achieve reasonable international levels of investment in science and technology and to overcome a situation of continuous lagging behind on the international scene. This has been shown to be associated with patterns of relatively sluggish or fluctuating investments in research and development (R\&D) for many years, reaching unparalleled levels of development only in the period 2007-2010. This is the period associated with a short period of brain gain of PhDs to Portugal, which was observed only until recession and budgetary problems overtook Portugal and the rest of Europe (Heitor et al., 2014).

Recent years have been characterized by a decrease in the budget allocated to science and technology (S\&T), associated with the perception that policies must be changed. In this regard, two types of arguments have been put forward, often conflicting and possibly resulting from distinct political influences (Heitor, 2015). On the one hand, there is a recurrent argument in Portugal that there is a need to target public support for companies and mostly for business competitiveness, and, on the other hand, a need to increase selectivity criteria of public support based on the claim of overqualified personnel. This has resulted, for example, in the reduction of funds allocated to doctoral and post-doctoral grants and scientific employment.

\section{Data analysis}

This section focuses on five main analytical issues drawn from the literature. The first concerns the stocks and flows of highly qualified resources (see Loyalka et al., 2014), which this article adapts to the doctorate holder population. The second and third issues relate to the qualifications and age distribution of academic staff at Portuguese universities and the stock of doctorate holders. These two issues have attracted increased interest in the literature since they are believed to have an impact on the quality of research, teaching, and other services that universities provide to society (see Sarrico and Alves, 2015; Sarrico and Pinheiro, 2015). The fourth issue concerns the specific contribution of the stock and flows of doctorates to research output, relative to mature scientific systems (Pinheiro et al., 2014). The final issue is related to the employability of doctorates in non-academic sectors (Castro-Cruz and Sanz-Menéndez, 2005).

\subsection{Doctorate flows and stocks in Portugal and Europe}

Europe is the region in the world training the highest number of new doctorates per year. According to the European Commission, the European Union, "with 111,000 new doctorates awarded every year, produces nearly twice as many doctorates as the United States." (European Commission, 2011). Although the overall number of new doctorates has been increasing steadily in Europe (Fig. 1), this figure gives no indication of the big difference between countries, with Finland, Germany and the UK exhibiting considerably larger numbers than all other countries.

The Portuguese ratio of new doctorate holders in relation to the population has increased substantially over the last decades, but in 2004, it was still one of the lowest in Europe. The ratio for 2012 was comparable to that in Belgium and The Netherlands for 2004 and about 40\% lower than that in mature scientific and academic countries such as the UK, Germany or Finland, where the discourse of "too many PhDs" may be more prominent.

Although the stock of doctorate holders in Portugal (relative to the population) has been on the rise in recent years, it is still a long way from matching that of other countries such as Germany or Finland (see Fig. 2). Indeed, Portugal only managed in 2012 to attain the stock that Netherlands had in 2004, which represents a significant lag in qualification. As of 2012, the Portuguese's relative stock of doctorate holders (23 PhDs per 10,000 inhabitants) is only less than half of Germany's in the same year (54 PhDs per 10,000 inhabitants). Given the decrease in the gross R\&D expenditure in recent years, from 1.6\% of GDP in 2010 to $1.34 \%$ in 2013 , it is unlikely that Portugal will match other European Union countries in the foreseeable future, especially when considering that the flow of new doctorate holders is expected to start decreasing in 2015 (Heitor, 2015).

By combining the information presented above and plotting the stock versus the flow of PhDs for Portugal in comparison with other European countries it is possible to obtain further insights (see Fig. 3). The trend-lines exhibit a quite different path in the countries considered, with Portugal following the Dutch pattern, but quite different from the situation in Finland. In the case of Portugal, it is also important to note that the path is almost linear because the growth rate of the stock does not match what would be expected by the two-fold increase in the flow of new doctorate holders between 2004 and 2012. A possible 


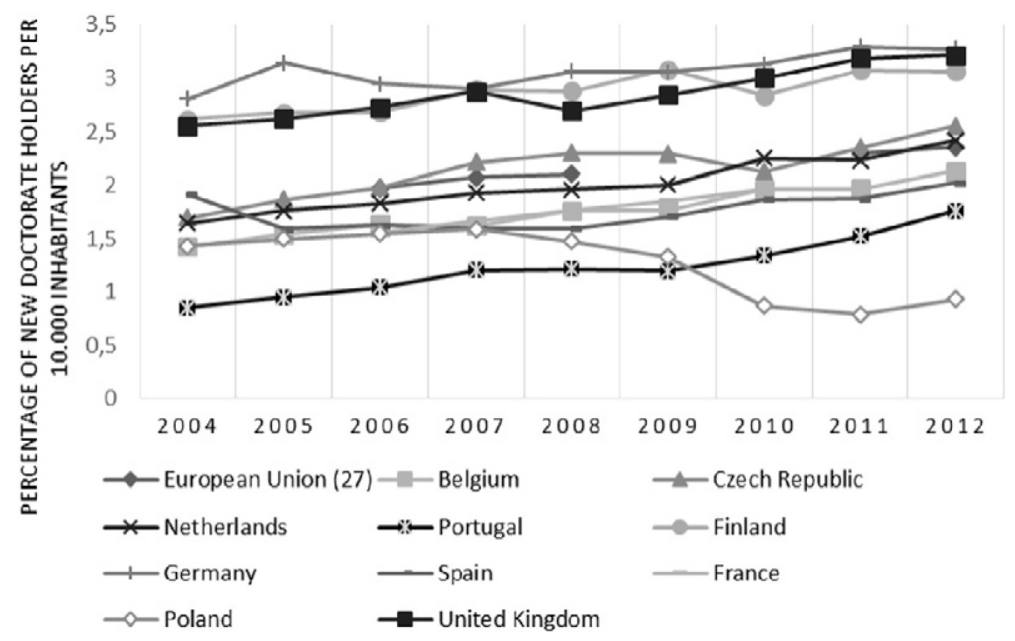

Fig. 1. Flow of new PhDs, as measured by the number of new PhDs per 10,000 inhabitants, 2004-2012. Source: Educational attainment and education outcomes (EDAT), Eurostat.

reason for this is that a significant portion of newly-graduated doctorates do not remain in the country, creating an additional challenge for Portugal in terms of the emergence of a new era of brain drain (see Heitor, 2015).

\subsection{The qualification level of the Portuguese higher education teaching body}

Expanding the previous analysis, the employment of doctorate holders is considered in the following sectors of activity: business enterprises, government, higher education, private non-profit, and other types of education. A trend which can be identified in Portugal, and also in some other countries (see Fig. 4), is the concentration of doctorate holders in the higher education and government sectors (respectively $85 \%$ and $8 \%$ ). Most notably, the business enterprise sector in Portugal employs very few doctorate holders (3\%), mostly because of the structure of the economy and the relative concentration of small size firms that tend not to employ them, unless they are from knowledge intensive sectors (Heidenreich, 2009).

This analysis is important for two reasons. First, it confirms a substantial difference across countries in terms of the diversification of the employability of doctorate holders, with countries having welldeveloped scientific and economic systems being able to have open highly skilled labor markets in the private sector (i.e., The Netherlands and Belgium). The related migration of doctorate holders from academia to non-academic sectors is only relevant in countries with developed high-tech sectors (Thune, 2009), which are increasingly drivers of the ongoing international competition for skilled human resources. Second, it suggests that higher education and government sectors in Portugal and other comparatively less developed European regions should increase employment opportunities for new doctorate holders in order to retain and attract PhDs at home (De Grande et al., 2014; Roach and Sauermann, 2010).

When considering the evolution of the qualifications of academic staff in Portuguese universities, one observes that the percentage of academic staff holding a PhD is still only about $70 \%$ in public universities and below $50 \%$ in private universities (with reference to 2012/ 2013, see Fig. 5). The data also show a rapid increase in the qualifications of university academic staff in the early 2000s but a relative stagnation in that process over the few last years. The large qualification gap between academic staff in public and private universities can be explained by the strong teaching orientation of private universities and their focus on social sciences and humanities (Amaral and Teixeira, 2000; Teixeira et al., 2012). However, the key point to stress from this analysis is that there is a great opportunity to enhance the qualifications of academic staff in Portuguese higher education, which exhibits rather low qualification levels when compared to other OECD countries.

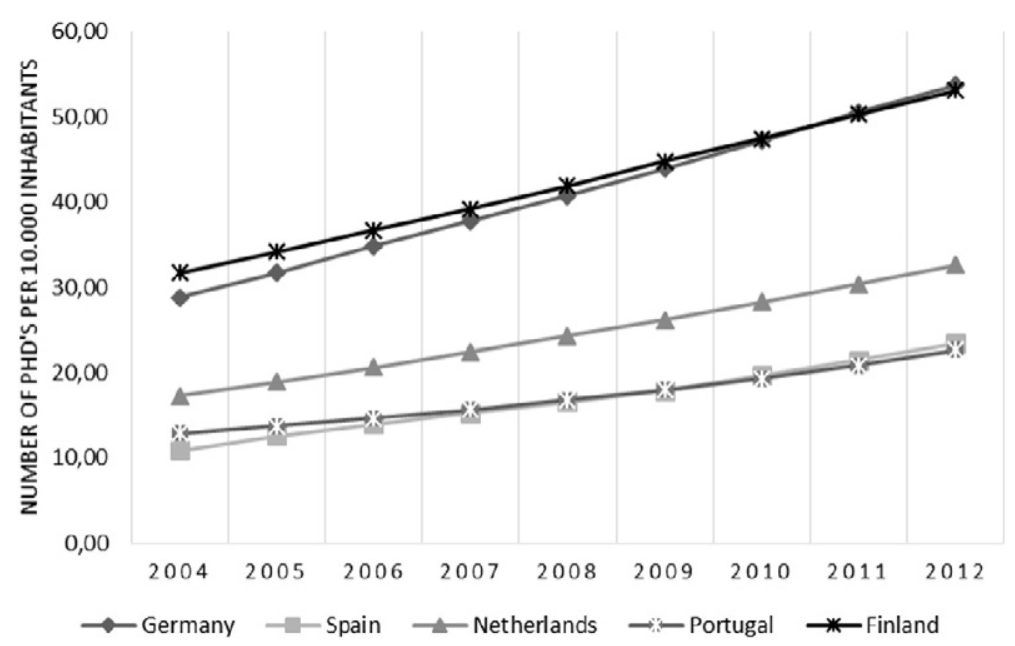

Fig. 2. Relative stock of PhDs, as measured by the total number of PhDs by 10,000 inhabitants, 2004-2012. Source: OECD, own calculations. 


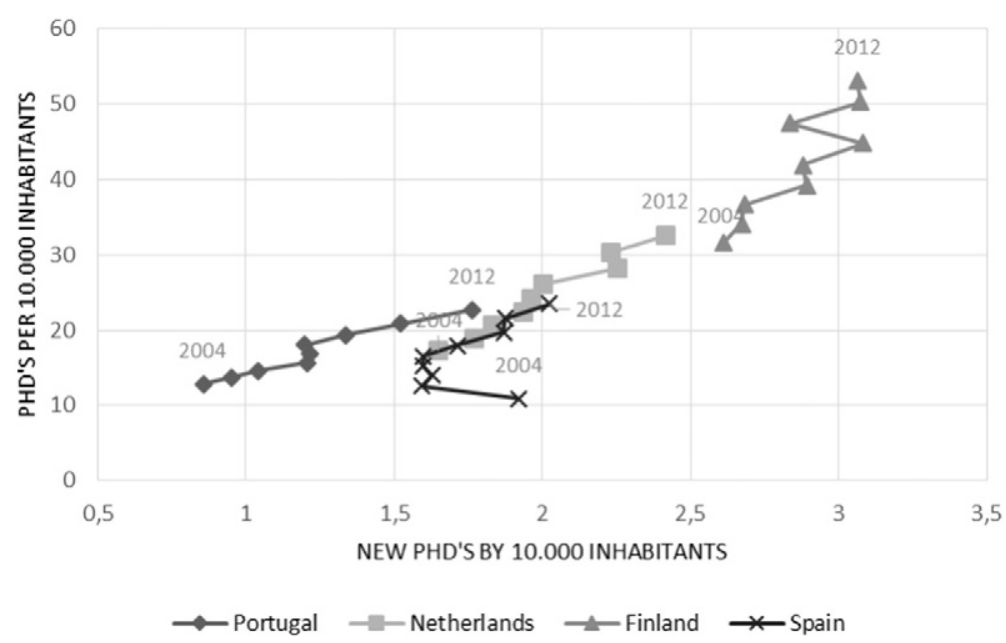

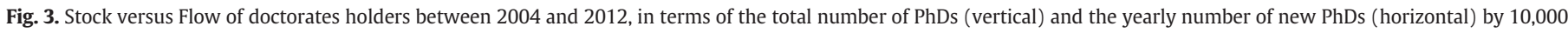
inhabitants.

Source: OECD, own calculations.

The national and institutional average figures reported above give no indication of the different rates of evolution in specific disciplinary fields. However, this is a matter of relevance. For example, Heitor et al. (2014) showed distinct institutional and disciplinary paths in the qualifications of academic staff in the faculties of medicine, engineering and law in three different Portuguese universities. On average, engineering faculties have been the fastest in adopting the $\mathrm{PhD}$ as a necessary qualification for their academic staff, while the qualifications of academic staff in faculties of medicine have either stagnated or actually worsened in recent years. This is an indication not only of the importance of specific disciplinary cultures, norms and habits, but also of how different levels of engagement in research are also influential factors in the Portuguese case.

\subsection{Aging of the Portuguese doctorate population and academic staff}

The issue of relative low qualifications of academic staff at Portuguese universities cannot be solely perceived from an historical and institutional perspective. Although the data discussed above suggests that the argument of "too many PhDs" is not appropriate, it should be noted that further analysis of the age and retirement conditions in academia needs to be considered.
The age distribution of the population of doctorate holders in Portugal has changed considerably over the years, together with the stock of doctorate holders (see Fig. 6). Whereas in the 1970s, the total stock of doctorate holders (with less than 400 doctorate holders) comprised only individuals over 55 years old, in the 2000s, the stock increased to over 25 thousand people, $92 \%$ of whom below 55 years old, including $67 \%$ below 44 years old. The population of doctorate holders in Portugal became younger mostly as the result of public policies fostering a steep increase in the number of doctorate doctoral students through doctoral grants (Horta and Hasanefendic, 2015). The number of doctorates awarded in the period 2000 to 2009 was greater by $48 \%$ than the total number of doctorates awarded in the three previous decades, from 1970 to 1999 (Heitor and Horta, 2012).

An international comparison of the age distribution of the stock of doctorate holders in several countries indicates that Portugal is characterized by an age distribution that is still comparatively skewed towards the older strata (see Fig. 7). This implies the need for Portugal to continue investing in doctoral education and promoting the systematic rejuvenation of the stock of doctorate holders. It should also be noted that the age distribution of doctorate holders in Portugal may appear similar to that in the USA and Finland, but those countries have long been able to constantly attract highly qualified people from abroad as a strategy for augmenting human capital (Lee, 2014; Suter and Jandl, 2008).

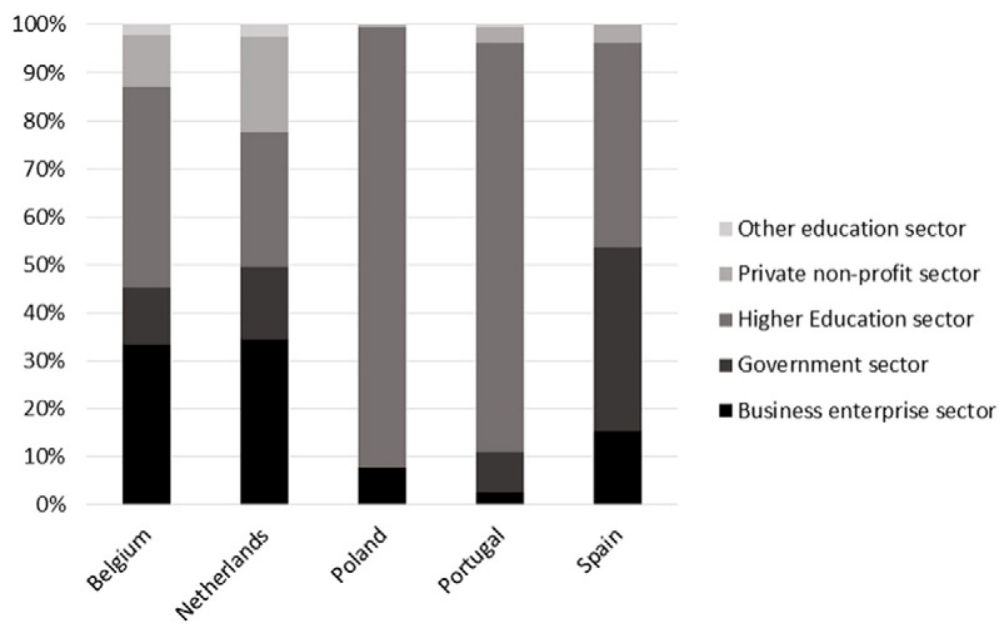

Fig. 4. Sectorial distribution of doctorate holders in 2009

Source: CDH 2009 data collection, OECD. 


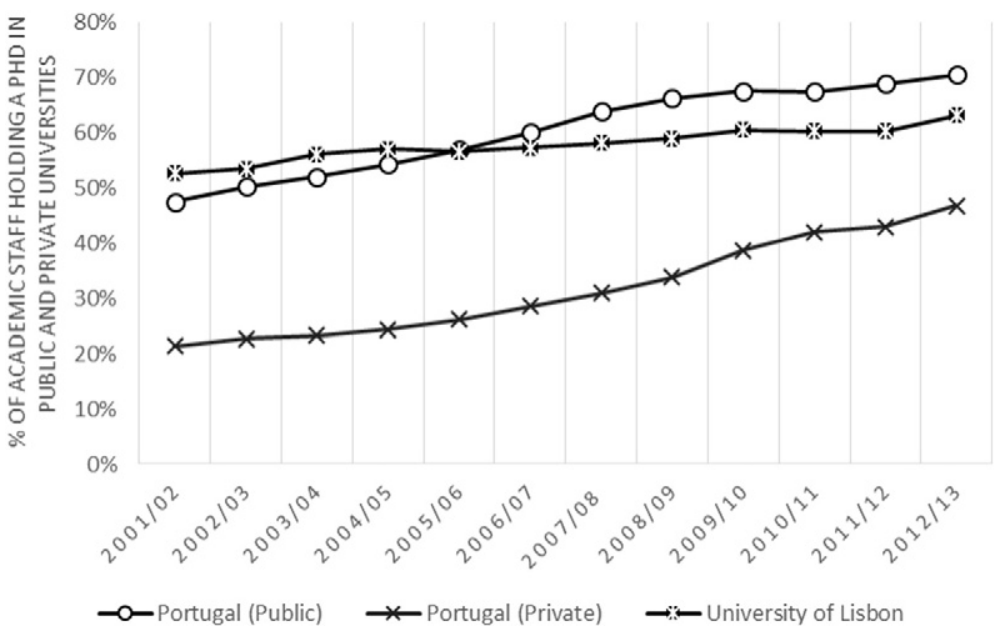

Fig. 5. Sample data about the percentage of teaching body holding a PhD in Portugal. Note: Polytechnic institutions not included. Source: Ministry of Science and Education (Portugal).

The analysis in Fig. 7 reinforces the findings of Fig. 6 in that the increasing international competition for skilled human resources does require a continuous investment in the training of young doctoral students. This is particularly important for countries like Portugal, where most of the doctorate holders are employed by a still underqualified higher education system, in which academic staff are aging fast. According to our estimations based on official data, it is expected that $41 \%$ of academic staff in public universities and $34 \%$ of academic staff in private universities will retire within the next 15 years. Those retiring within the next 5 to 7 years represent around $10 \%$ of the academic staff in public universities and 15\% of the academic staff in private universities, many of them holding a $\mathrm{PhD}$. Consequently, there will be a high demand for new PhDs in higher education in Portugal for years to come, requiring an adequate regulatory system and employment measures (Heitor, 2015).

\subsection{The evolving level of scientific production}

A further issue to be considered is the role of doctorate training in the growth of research output in Portugal, which is analyzed from the dual perspective of the stock (Fig. 8) and the flow (Fig. 9) of PhDs. The data show statistically significant and positive associations between the stock and the flow of PhDs and knowledge produced in Portugal, although it is clear that such correlations are not sufficient to make a causality claim between these variables. Nevertheless, there is a wide range of literature supporting the impact of the stock of doctorate holders and doctoral training on research productivity, so it is highly unlikely that the correlation is purely spurious. For example, Jairam and Kahl (2012) and Mowbray and Halse (2010) provide evidence of the development of doctoral skills for producing new research work, and Jackson (2013) underlines the role of doctoral education in promoting collaboration with external stakeholders. Other authors have emphasized the contribution of doctoral students to the pool of knowledge (e.g., Pinheiro et al., 2014).

Following this line of thought, and following Larivière's (2011) study of the contribution of doctoral students to knowledge output in the Canadian province of Quebec, an analysis of the relations between flows and stocks of PhDs and publications and citations was performed. The analysis showed that the number of internationally indexed publications affiliated with Portuguese institutions has increased in an almost perfect linear trend with the stock $\left(r^{2}=0.977\right)$ and flow $\left(r^{2}=0.907\right)$ of doctorate holders. The best trend line fit is an exponential line for

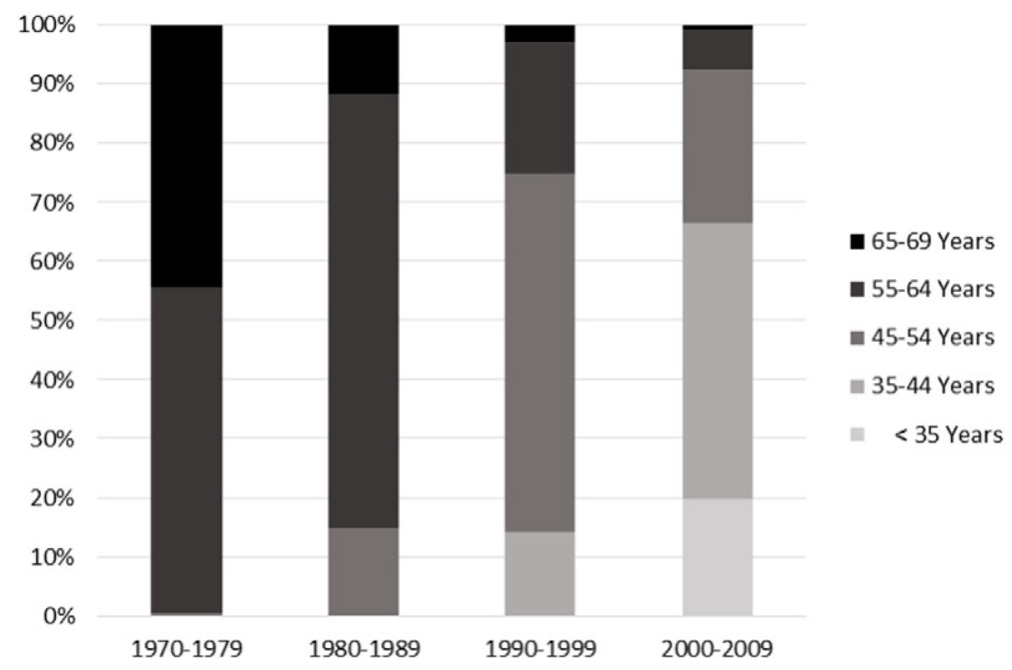

Fig. 6. Evolution of the age distribution of doctorate holders in Portugal over 4 decades. Source: DGEEC. 


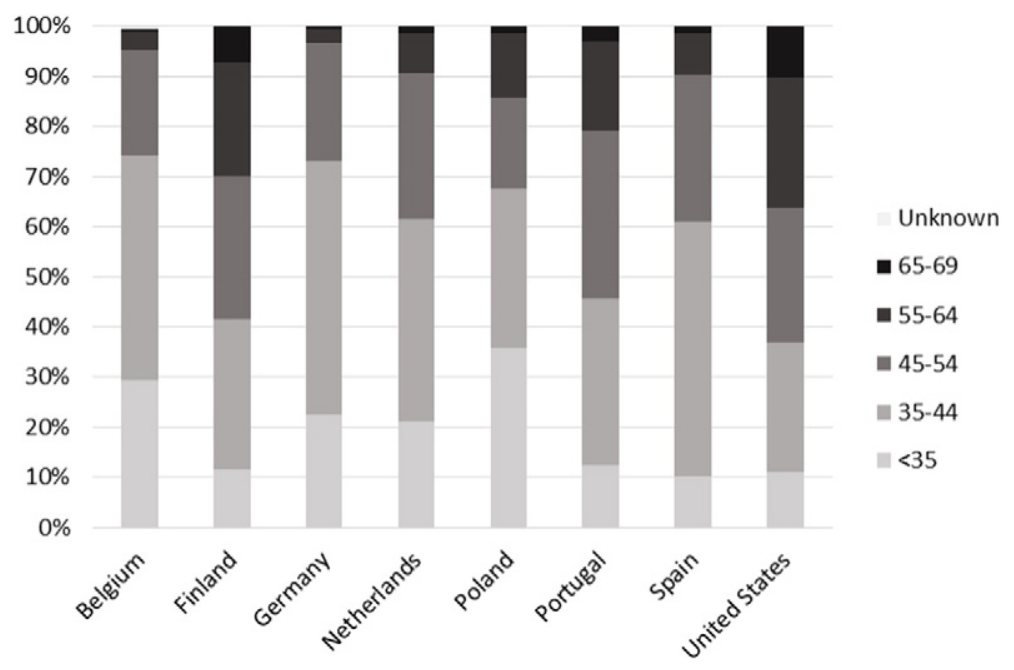

Fig. 7. Distribution of doctorate holders in several countries by age group in 2009 . Source: CDH 2009 data collection, OECD.

both the stock $\left(r^{2}=0.990\right)$ and the flow $\left(r^{2}=0.932\right)$ of doctorate holders, suggesting that increasing the stock of doctorate holders fosters knowledge production significantly, at least as quantified in terms of publications. The effect of the training of PhDs in Portugal is also evident in the impact of the internationally indexed publications affiliated with Portuguese institutions, with statistically significant correlations between the citation impact and both the stock of doctorate holders $(\mathrm{r}=0.974 ; \mathrm{p}<0.001)$ and the flow of doctorate holders $(\mathrm{r}=0.954$; $\mathrm{p}<0.001)$.

\subsection{Non-academic labor market for doctorates}

Phelps (2013), among other scholars, refers to the need for available highly qualified people as a condition for high technology sectors to emerge and develop. At the same time, a major concern in mature scientific systems is the lack of available positions in academia for doctorate holders and the sets of skills that doctorate holders require to be employed in non-academic sectors (e.g., De Grande et al., 2014). This issue is usually understood as both a challenge and an opportunity in these systems, with implications for systems still in the developing stages, even considering the need for PhDs to improve qualifications in the academic sector.

Although the employment of doctorate holders in the business enterprise sector is critical to the promotion of knowledge transfer and innovation (Heidenreich, 2009), this occurs mainly in high and medium-high technology sectors, which represent about $11 \%$ of employment in Germany and 7\% in Finland, and only 3\% in Portugal. In addition, Heitor (2015) has shown that only those European nations that have increased their investment in S\&T and, at the same time, managed to diversify their economic structure (i.e., Germany and The Netherlands) have guaranteed the necessary absorptive capacity to foster the creation of skilled jobs and promote the impact of S\&T in economic development (see also Cohen and Levinthal, 1990; Freel, 2005; Vinding, 2004). The implications for countries developing their scientific systems are that they need to increase the budget allocated to R\&D with measures oriented towards technological diversification and intensification of the industrial base across different sectors. Instead of calling for the creation of new highly qualified jobs in business sectors that cannot seem to accommodate them in the short-term (Garcia-Quevedo et al., 2012), the focus may

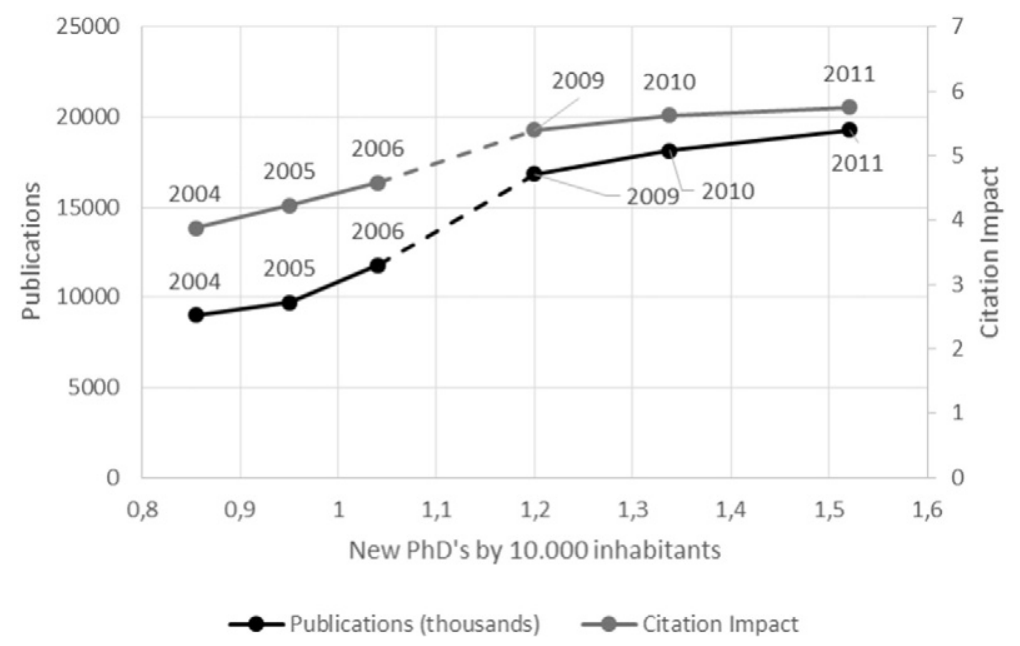

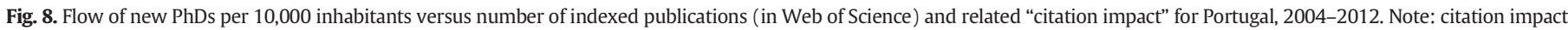

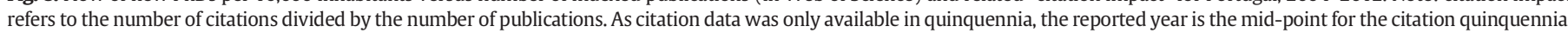
Inconsistent data between 2006 and 2009 is reported here as a series break. 


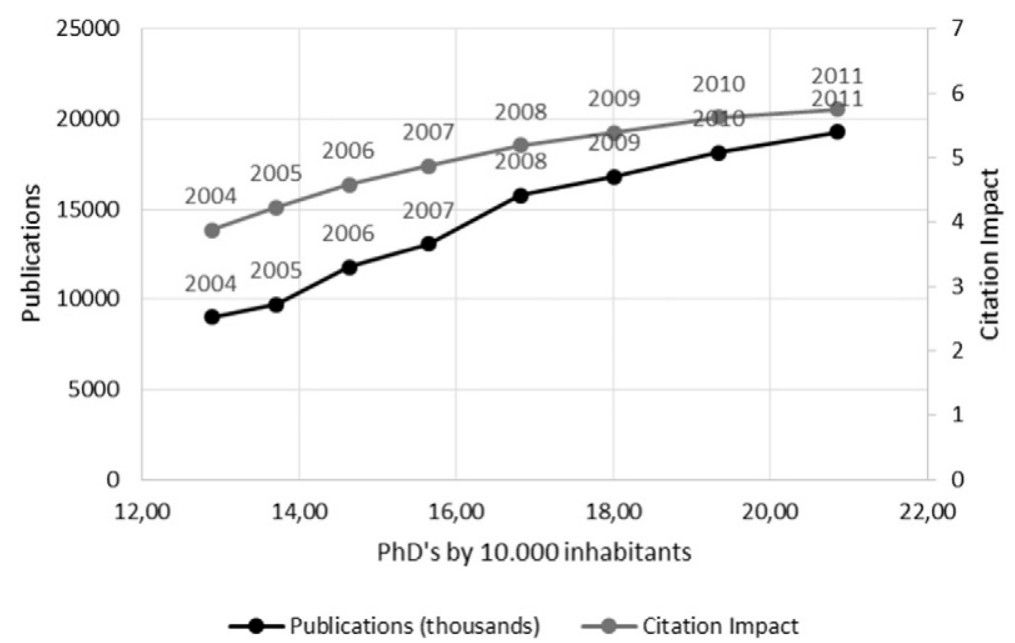

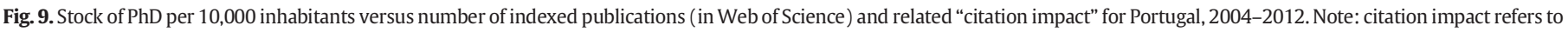
the number of citations divided by the number of publications. As citation data was only available in quinquennia, the reported year is the mid-point for the citation quinquennia. Sources: OECD; DGEEC; own calculations.

need to be directed to create the conditions necessary for the market for PhDs to develop in time.

Also, a discussion on the employability of doctorates in nonacademic sectors needs to consider the public administration sector, which is facing large economic, social and political pressures for reform (see OECD, 2013), as well as the need to consider qualified human resources as a strategic asset (McGregor, 1988). Fig. 10 quantifies the evolution of the levels of formal qualifications in the Portuguese public administration over the last decade, showing a quasi-stagnant level of only half of the workers possessing a tertiary education degree, with only $9 \%$ possessing a doctorate or a master's degree in 2014, including teachers and medical doctors. Refining the analysis, by subtracting the ministries of health, science and education, those with doctorates and master's degrees represented only $5 \%$ of the total number of public employees in 2014 , with the percentage of workers with tertiary education dropping to $37 \%$. In general, the data suggests that public administration represents an effective potential for doctorate employment in Portugal. However, this requires active public policies to foster the employment of highly qualified people in this sector.

\section{Discussion: the role of public policy in fostering the changing nature of PhDs}

The analysis presented above contradicts arguments that there are "too many PhDs" in Portugal. At the same time, it underlines the relevance that public policies and instruments emphasizing doctoral training and employment had and may have for the years to come. Although these instruments (Table 1) have recently been questioned in Portugal, they contributed decisively to strengthening the science, technology and higher education systems in the country for the past decades. Table 1 shows a long-term process of human capital formation associated to institutional building policies (see Rodrigues and Heitor, 2015), that required different institutional speeds, where four main issues should be underlined: i) the required accumulation over time of individual grants at doctoral and post-doctoral levels; ii) the nature of increasingly open competitions for individual grants, including the need to attract foreign nationals; iii) the need to evolve from grants to research contracts, at least at the post-doctoral level and on a temporary basis; and iv) the need to consider some level of academic inbreeding in the oldest universities in order to facilitate the building of local absorptive capacity.

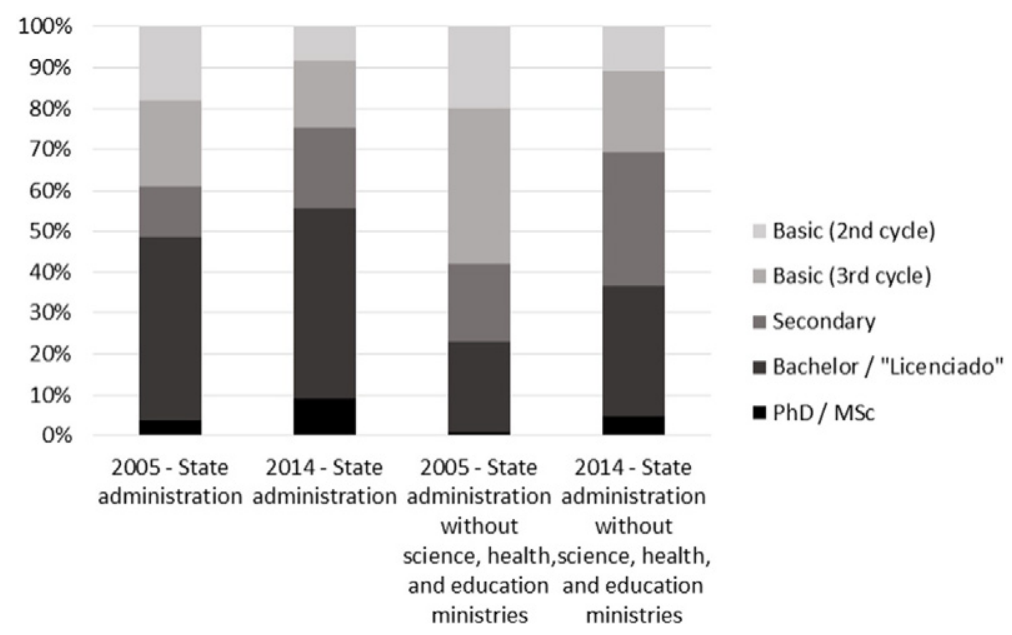

Fig. 10. Formal educational level of public administrators in Portugal, for 2005 and 2014. Source: DGAEP. 
Table 1

Main periods analyzed in this article for the development of doctorate training and science policy in Portugal (1970-2015).

\begin{tabular}{|c|c|c|c|c|c|}
\hline Period & Main characteristics & GERD/GDP & $\begin{array}{l}\text { Typical flow of PhDs } \\
\text { (number of new PhDs } \\
\text { per year) }\end{array}$ & $\begin{array}{l}\text { Typical stock of PhDs } \\
\text { (total number of PhDs) }\end{array}$ & Main S\&T policy instruments \\
\hline 1970-1985 & $\begin{array}{l}\text { Early attempts at growth, with } 50 \% \text { of } \\
\text { PhDs abroad; few PhDs in universities } \\
\text { (brain drain); high academic inbreeding }\end{array}$ & $0.27 \%$ & $\begin{array}{l}150 \\
\text { (in 1985) }\end{array}$ & Around 500 & $\begin{array}{l}\text { Creation of several universities in the mid-1970s } \\
\text { (higher education policy); definition of university } \\
\text { and polytechnic career statutes. }\end{array}$ \\
\hline 1986-1995 & $\begin{array}{l}\text { Striving to increase knowledge capacity; } \\
\text { greater mobility to international } \\
\text { scientific organizations (e.g., CERN); high } \\
\text { academic inbreeding }\end{array}$ & $0.48 \%$ & $\begin{array}{l}400 \\
\text { (in 1995) }\end{array}$ & Around 3000 & $\begin{array}{l}\text { Infrastructure building, competitive R\&D projects } \\
\text { and individual fellowship program (doctoral and } \\
\text { post-doctoral); below } 30 \% \text { of PhDs in the faculty of } \\
\text { public universities }\end{array}$ \\
\hline 1996-2005 & $\begin{array}{l}\text { Doctoral and post-doctoral fellowship } \\
\text { program, increased brain circulation }\end{array}$ & $0.75 \%$ & $\begin{array}{l}1100 \\
\text { (in 2005) }\end{array}$ & Around 12,000 & $\begin{array}{l}\text { Performance-based funding of research units, } \\
\text { through national research assessments, including } \\
\text { the creation of large associate laboratories, to foster } \\
\text { research networks; research career status; } \\
\text { promotion of public understanding of science; 50\% } \\
\text { of PhDs in the faculty of public universities }\end{array}$ \\
\hline 2006-2010 & $\begin{array}{l}\text { Increasing capacity; research contracts } \\
\text { (achieving brain gain of PhDs) }\end{array}$ & $1.5 \%$ & $\begin{array}{l}1500 \\
\text { (in 2010) }\end{array}$ & Around 25,000 & $\begin{array}{l}\text { New measures to foster scientific employment } \\
\text { through competitive research contracts; university } \\
\text { chairs; reform of university governance and } \\
\text { assessment systems; International partnerships } \\
\text { promoting thematic networks of research and } \\
\text { advanced training; } 60 \% \text { of PhDs in the faculties of } \\
\text { public universities }\end{array}$ \\
\hline 2011-2015 & $\begin{array}{l}\text { Austerity, with increasing divergence to } \\
\text { Europe }\end{array}$ & $1.3 \%$ & $\begin{array}{l}2500 \\
\text { (in 2014) }\end{array}$ & Around 30,000 & $\begin{array}{l}\text { Stagnant levels of scientific employment and } \\
\text { university positions; } \\
70 \% \text { of PhDs in the faculty of public universities }\end{array}$ \\
\hline
\end{tabular}

Note: The calculation of GDP follows the European System of Accounts, ESA 2010 revision.

The descriptive statistics presented in this article also address the employment of doctorate holders in non-academic sectors. The creation of skilled jobs and the diversification of the economy are key issues that are increasingly associated with doctoral training. In this regard, it should also be noted that research outcomes tend to be characterized by strong spillover effects. From the point of view of companies, this leads to an underinvestment in R\&D because the appropriation of benefits of that investment is not complete (Conceição et al., 2004). The conclusion is that public policies geared towards increasing private expenditure in R\&D and skilled employment should embrace increasing public expenditure, which is counter-intuitive in light of a "linear" interpretation of the innovation generating mechanisms. When tracking the trajectory of the countries today that mostly invest in private funds in R\&D together with the employment of doctorate holders, one realizes that this private funding has been historically preceded by intense and sustained public investments in R\&D (e.g., Mazzucato, 2013).

In this context, besides public investment, policies and regulatory frameworks that are oriented to stimulating doctoral education and employment, the role of "intermediary institutions" should be highlighted. Intermediary institutions encompass private partnerships, public-private partnerships, and non-governmental and contract research organizations with significant R\&D activities able to gain access to distributed knowledge bases through a pool of skilled employees These institutions represent potential employers of doctorate holders in a wide range of positions. The development of future markets (e.g., Cuhls et al., 2012) and the creation of new economic actors and sectors (Rothgang et al., 2011) are facilitated through these type of institutions, which provide a framework for research on high-tech applications by enabling collaboration across different sectors and technology fields, and which can play a role in creating the sustainable employment of doctorate holders.

It should also be noted that the traditional dividing line between sectors with companies performing high-tech and low-tech research with respect to business employers of doctorate holders is becoming blurred (Cuhls et al., 2012; Rothgang et al., 2011). Even within the familiar technological fields of many firms in low- and medium-technology industries, research questions arise that cannot be answered by firms using firm-internal sources or by merely implementing technology that has been developed elsewhere. Lessons learned from the trajectory of countries today, such as Germany, that mostly invest in private funds in $R \& D$ and in the employment of doctorate holders, suggest that public funded research networks and public-private partnerships may have critical roles in both "traditional" sectors of the manufacturing industry and the creation of new high tech sectors. By promoting precompetitive, cooperative research activities, together with $\mathrm{PhD}$ employment, public policies may facilitate the innovativeness of enterprises across the economy, contributing to its diversification.

\section{Conclusion}

This article contradicts the "too many PhDs" argument and argues that there is a need to understand better the changing nature of doctorates and doctorate holders and their possible future employment perspectives. The analysis is developed for Portugal as a case study of interest to other countries developing their science, technology and higher education systems. Our analysis suggests that there is a need for active public policies to attract and retain highly qualified human resources, and to promote new economic actors and instruments with the capacity to invest in and employ PhDs. The way in which a country like Portugal may gain competitiveness and access to external markets may require encouraging international knowledge and innovation networks, and deepening the degree of involvement of new doctorate holders in the internationalization of the economy. Intermediary institutions and public-private research partnerships may play a critical role in the process, implying necessarily a better understanding of the changing nature of doctorates and doctorate holders.

However, the need for more doctorate holders is beyond immediate economic rationales, and this article shows their basic role and continuous relevance in improving qualifications in higher education, as well as in sustaining a dynamic national science and technology base. The current economic situation presents a strategic opportunity to revisit the role of doctoral training in times of post-financial crisis. This requires strengthening doctoral education, together with new research partnerships, and counter-cycle policies that help in diversifying the employability of future doctorate holders. Efforts to enhance the employability of doctorate holders outside academia should take in consideration the need to change the structure of the economy and new forms of skilled employment in intermediate organizations, as well as in public administration. 


\section{References}

Alberts, B., Kirschner, M.W., Tilghman, S., Varmus, H., 2014. Rescuing US biomedical research from its systemic flaws. Proc. Natl. Acad. Sci. 111, 5773-5777. http://dx. doi.org/10.1073/pnas.1404402111.

Amaral, A., Teixeira, P., 2000. The rise and fall of the private sector in Portuguese higher education. High. Educ. Policy 13, 245-266.

Auriol, L., 2010. Careers of Doctorate Holders: Employment and Mobility Patterns. OECD Publishing.

Bleiklie, I., Kogan, M., 2007. Organization and governance of universities. High. Educ Policy 20, 477-493.

Breschi, S., Lenzi, C., Malerba, F., Mancusi, M.L., 2014. Knowledge-intensive entrepreneurship: sectoral patterns in a sample of European high-tech firms. Technol. Anal. Strateg. Manag. 1-14.

Byrne, J., Jørgensen, T., Loukkola, T., 2013. Quality Assurance in Doctoral Education: Results of the ARDE Project. European University Association, Brussels.

Canal Domínguez, J.F., Muñiz Pérez, M.A., 2012. Professional doctorates and careers: the Spanish case1. Eur. J. Educ. 47, 153-171.

Cantwell, B., 2011. Academic in-sourcing: international postdoctoral employment and new modes of academic production. J. High. Educ. Policy Manag. 33, 101-114.

Carneiro, A., Portugal, P., Varejao, J., 2014. Catastrophic job destruction during the Portuguese economic crisis. J. Macroecon. 39, 444-457.

Casey, B.H., 2009. The economic contribution of PhDs. J. High. Educ. Policy Manag. 31, 219-227. http://dx.doi.org/10.1080/13600800902974294.

Castro-Cruz, L., Sanz-Menéndez, L., 2005. The employment of PhDs in firms: trajectories, mobility, and innovation. Res. Eval. 14 (1), 57-69.

Cattaneo, M., Meoli, M., Signori, A., 2014. Performance-based funding and university research productivity: the moderating effect of university legitimacy. J. Technol. Transfer. http://dx.doi.org/10.1007/s10961-014-9379-2.

Chaloff, J., Lemaitre, G., 2009. Managing Highly-Skilled Labour Migration: A Comparative Analysis of Migration Policies and Challenges in OECD Countries. OECD Publishing.

Cishe, E., 2014. Fostering quality teaching and learning in higher education through academic staff development: challenges for a multi-campus university. Mediterr. J. Soc. Sci. 5, 272.

Cohen, W.M., Levinthal, D.A., 1990. Absorptive capacity: a new perspective on learning and innovation. Adm. Sci. O. 128-152.

Conceição, P., Heitor, M.V., Sirilli, G., Wilson, R., 2004. The "swing of the pendulum" from public to market support for science and technology: is the U.S. leading the way? Technol. Forecast. Soc. Change 71, 553-578. http://dx.doi.org/10.1016/j.techfore. 2004.03.002.

Craswell, G., 2007. Deconstructing the skills training debate in doctoral education. High. Educ. Res. Dev. 26, 377-391.

Cuhls, K., Bunkowski, A., Behlau, L., 2012. Fraunhofer future markets: from global challenges to dedicated, technological, collaborative research projects. Sci. Public Policy 39, 232-244.

Cuthbert, D., Molla, T., 2014. PhD crisis discourse: a critical approach to the framing of the problem and some Australian "solutions". High. Educ. http://dx.doi.org/10.1007/ s10734-014-9760-y.

Cyranoski, D., Gilbert, N., Ledford, H., Nayar, A., Yahia, M., 2011. Education: the PhD factory. Nature $472,276-279$.

De, S., 2014. Intangible capital and growth in the "new economy": implications of a multisector endogenous growth model. Struct. Change Econ. Dyn. 28, 25-42.

De Grande, H., De Boyser, K., Vandevelde, K., Van Rossem, R., 2014. From academia to industry: are doctorate holders ready? J. Knowl. Econ. 5, 538-561.

Delanty, G., 2002. Challenging Knowledge: The University in the Knowledge Society.

Durette, B., Fournier, M., Lafon, M., 2014. The core competencies of PhDs. Stud. High. Educ. $1-16$.

Enders, J., 2002. Serving many masters: the PhD on the labour market, the everlasting need of inequality, and the premature death of humboldt. High. Educ. 44, 493-517.

European Comission, 2011. Innovation Union Competitiveness Report - Executive Summary. European Comission, Brussels.

Fenge, L., 2009. Professional doctorates - a better route for researching professionals? Soc. Work. Educ. 28, 165-176. http://dx.doi.org/10.1080/02615470701865733.

Ferlie, E., Musselin, C., Andresani, G., 2008. The steering of higher education systems: a public management perspective. High. Educ. 56, 325-348.

Forfás, I., 2009. The Role of PhDs in the Smart Economy.

Freel, M.S., 2005. Patterns of innovation and skills in small firms. Technovation 25, 123-134.

Garcia-Quevedo, J., Mas-Verdú, F., Polo-Otero, J., 2012. Which firms want PhDs? An analysis of the determinants of the demand. High. Educ. 63, 607-620.

Guerin, C., Jayatilaka, A., Ranasinghe, D., 2015. Why start a higher degree by research? An exploratory factor analysis of motivations to undertake doctoral studies. High. Educ. Res. Dev. 34, 89-104.

Heidenreich, M., 2009. Innovation patterns and location of European low-and mediumtechnology industries. Res. Policy 38, 483-494.

Heitor, M., 2015. Science Policy for an Increasingly Diverging Europe. J. Res, Policy Eval In press.

Heitor, M., Horta, H., 2012. Science and technology in Portugal: from late awakening to the challenge of knowledge-integrated communities. Higher Education in Portugal 1974-2009. Springer, pp. 179-226.

Heitor, M., Horta, H., Mendonça, J., 2014. Developing human capital and research capacity: science policies promoting brain gain. Technol. Forecast. Soc. Change 82 $6-22$.

Horta, H., 2010. The role of the state in the internationalization of universities in catchingup countries: an analysis of the Portuguese higher education system. High. Educ Policy 23, 63-81.
Horta, H., Hasanefendic, S., 2015. Young doctorates in a fast-changing higher education system: the case of Portugal. In: Yudkevich, M., Altbach, P., Rumbley, L. (Eds.), Young Faculty in the Twenty-First Century: International Perspectives. SUNY Press, Albany.

Horta, H., Santos, J.M., 2015. The Impact of Publishing During the PhD on Career Research Publications, Visibility, and Collaborations. Res. High, Educ.

Jackson, D., 2013. Completing a PhD by publication: a review of Australian policy and implications for practice. High. Educ. Res. Dev. 32, 355-368. http://dx.doi.org/10.1080/ 07294360.2012 .692666

Jairam, D., Kahl Jr., D.H., 2012. Navigating the doctoral experience: the role of social support in successful degree completion. Int. J. Dr. Stud. 7, 311-329.

Larivière, V., 2011. On the shoulders of students? The contribution of PhD students to the advancement of knowledge. Scientometrics 90, 463-481. http://dx.doi.org/10.1007/ s11192-011-0495-6.

Larson, R.C., Ghaffarzadegan, N., Xue, Y., 2014. Too many PhD graduates or too few academic job openings: the basic reproductive number R0 in academia. Syst. Res. Behav. Sci. 31, 745-750.

Lee, J.T., 2014. Education hubs and talent development: policymaking and implementation challenges. High. Educ. http://dx.doi.org/10.1007/s10734-014-9745-x.

Loyalka, P., Carnoy, M., Froumin, I., Dossani, R., Tilak, J., Yang, P., 2014. Factors affecting the quality of engineering education in the four largest emerging economies. High. Educ. 68, 977-1004.

Maldonado, V., Wiggers, R.D., Arnold, C., 2013. So You Want to Earn a PhD?: The Attraction, Realities, and Outcomes of Pursuing a Doctorate.

Mazzucato, M., 2013. The Entrepreneurial State: Debunking Public vs. Private Sector Myths. Anthem Press.

McGregor Jr., E.B., 1988. The public sector human resource puzzle: strategic management of a strategic resource. Public Adm. Rev. 48, 941-950. http://dx.doi.org/10.2307/ 976989.

Mertens, A., Robken, H., 2013. Does a doctoral degree pay off? An empirical analysis of rates of return of German Doctorate Holders. High. Educ. 66, 217-231.

Milesi, C., Selfa, L.A., Milan, L.M., 2014. Unemployment among doctoral scientists and engineers increased but remained below the national average (no). NSF 14-310. NSF National Center for Science and Engineering Statistics.

Miller, J.M., Feldman, M.P., 2014. The sorcerer's postdoc apprentice: uncertain funding and contingent highly skilled labour. Camb. J. Reg. Econ. Soc. rsu003.

Mowbray, S., Halse, C., 2010. The purpose of the PhD: theorising the skills acquired by students. High. Educ. Res. Dev. 29, 653-664. http://dx.doi.org/10.1080/07294360.2010. 487199.

OECD, 2013. Portugal: Reforming the State to Promote Growth, Better Policies Series. OECD, Paris.

Pedersen, H.S., 2014. New doctoral graduates in the knowledge economy: trends and key issues. Journal of Higher Education Policy and Management 36 (6), 632-645.

Phelps, E.S., 2013. Mass Flourishing: How Grassroots Innovation Created Jobs, Challenge, and Change. Princeton University Press.

Pinheiro, D., Melkers, J., Youtie, J., 2014. Learning to play the game: student publishing as an indicator of future scholarly success. Technol. Forecast. Soc. Change 81, 56-66. http://dx.doi.org/10.1016/j.techfore.2012.09.008.

Pion, G.M., Smith, D.D., Tyler, N.C., 2003. Career choices of recent doctorates in special education: their implications for addressing faculty shortages. Teach. Educ. Spec. Educ. J. Teach. Educ. Div. Counc. Except. Child. 26, 182-193.

Regets, M.C., 2007. Issues in High-Skilled International Migration. IJED, p. 5.

Roach, M., Sauermann, H., 2010. A taste for science? PhD scientists' academic orientation and self-selection into research careers in industry. Res. Policy 39, 422-434.

Rodrigues, M.L., Heitor, M., 2015. 40 anos de Políticas de Ciência e Ensino Superior. Almedina, Lisbon.

Rothgang, M., Peistrup, M., Lageman, B., 2011. Industrial collective research networks in Germany: structure, firm involvement and use of results. Ind. Innov. $18,393-414$

Santos, J., Horta, H., 2015. The generational gap of science: a dynamic cluster analysis of doctorates in an evolving scientific system. Scientometrics 1-26. http://dx.doi.org/ 10.1007/s11192-015-1558-X.

Sarrico, C.S., Alves, A.A., 2015. Academic staff quality in higher education: an empirical analysis of Portuguese public administration education. High. Educ. 1-20.

Sarrico, C.S., Pinheiro, M.M., 2015. The characteristics of Portuguese management academics and their fit with teaching accreditation standards. Manag. Decis. 53, 533-552.

Schwartz, J.M., 2014. Resisting the exploitation of contingent faculty labor in the neoliberal university: the challenge of building solidarity between tenured and non-tenured faculty. New Polit. Sci. 36, 504-522.

Scott, P., 2000. Globalisation and higher education: challenges for the 21st century. J. Stud. Int. Educ. 4, 3-10.

Stephan, P., 2012a. Research efficiency: perverse incentives. Nature 484, 29-31.

Stephan, P., 2012b. How Economics Shapes Science. Harvard University Press Cambridge, MA.

Suter, B., Jandl, M., 2008. Train and retain: national and regional policies to promote the settlement of foreign graduates in knowledge economies. J. Int. Migr. Integr. Rev. Integr. Migr. Int. 9, 401-418. http://dx.doi.org/10.1007/s12134-008-0072-x.

Tavares, O., Cardoso, S., Carvalho, T., Sousa, S.B., Santiago, R., 2015. Academic inbreeding in the Portuguese academia. High. Educ. 69, 991-1006.

Teixeira, P.N., Rocha, V., Biscaia, R., Cardoso, M.F., 2012. Competition and diversity in higher education: an empirical approach to specialization patterns of Portuguese institutions. High. Educ. 63, 337-352.

Thune, T., 2009. Doctoral students on the university-industry interface: a review of the literature. High. Educ. 58, 637-651. http://dx.doi.org/10.1007/s10734-0099214-0. 
Usher, R., 2002. A diversity of doctorates: fitness for the knowledge economy? High. Educ. Res. Dev. 21, 143-153. http://dx.doi.org/10.1080/07294360220144060.

Vinding, A.L., 2004. Human resources, absorptive capacity and innovative performance. "Prod. Innov. Interact. Learn. Econ. Performance" Christ. Lundvall Oxf. Elsevier, pp. $155-178$ Ltd.

Wellington, J., Sikes, P., 2006. "A doctorate in a tight compartment": why do students choose a professional doctorate and what impact does it have on their personal and professional lives? Stud. High. Educ. 31, 723-734. http://dx.doi.org/10.1080/ 03075070601004358

Wildy, H., Peden, S., Chan, K., 2013. The rise of professional doctorates: case studies of the doctorate in education in China, Iceland and Australia. Stud. High. Educ. 1-14.

Zhou, J., 2014. Persistence motivations of Chinese doctoral students in science, technology, engineering, and math. J. Divers. High. Educ. 7, 177.
João M. Santos is a researcher based at the Instituto Universitário de Lisboa (ISCTE-IUL) in Portugal. He is currently pursuing a PhD in Psychology, with the goal of exploring the determinants of scientific agendas in researchers.

Hugo Horta is an assistant professor at the faculty of education at the University of Hong Kong. He is currently one of the coordinating editors of higher education (Springer) and sits in the editorial board of several journals including Higher Education Policy and Asia-Pacific Education Review.

Manuel Heitor is a full professor at Instituto Superior Técnico, IST, the engineering schoo of the University of Lisbon, and served as Secretary of State for Science, Technology and Higher Education in the government of Portugal from March 2005 to June 2011. 